Article

\title{
Energy Profiling of a High-Altitude Kyrgyz Community: Challenges and Motivations to Preserve Floodplain Ecosystems Based on Household Survey
}

\author{
Kedar Mehta ${ }^{1, *}$ (D) Mathias Ehrenwirth ${ }^{1}$, Siegmund Missall ${ }^{2}$, Nadira Degembaeva ${ }^{3}$, Kuban Akmatov ${ }^{3}$ \\ and Wilfried Zörner ${ }^{1}$ \\ 1 Institute of New Energy Systems, Technische Hochschule, 85049 Ingolstadt, Germany; \\ mathias.ehrenwirth@thi.de (M.E.); wilfried.zoerner@thi.de (W.Z.) \\ 2 Faculty of Forest and Environment Department, Eberswalde University for Sustainable Development, \\ 16225 Eberswalde, Germany; siegmund.missall@hnee.de \\ 3 Department of Agrarian-Technical, Naryn State University, Naryn 722600, Kyrgyzstan; \\ dknadira@gmail.com (N.D.); kubanakmatov_86@mail.ru (K.A.) \\ * Correspondence: kedar.mehta@thi.de; Tel.: +49-841-9348-6681
}

Citation: Mehta, K.; Ehrenwirth, M.; Missall, S.; Degembaeva, N.; Akmatov, K.; Zörner, W. Energy Profiling of a High-Altitude Kyrgyz Community: Challenges and Motivations to Preserve Floodplain Ecosystems Based on Household Survey. Sustainability 2021, 13, 13086. https://doi.org/10.3390/ su132313086

Academic Editors: Ivo Machar and Bernd Cyffka

Received: 30 October 2021

Accepted: 21 November 2021

Published: 26 November 2021

Publisher's Note: MDPI stays neutral with regard to jurisdictional claims in published maps and institutional affiliations.

Copyright: (c) 2021 by the authors. Licensee MDPI, Basel, Switzerland. This article is an open access article distributed under the terms and conditions of the Creative Commons Attribution (CC BY) license (https:/ / creativecommons.org/licenses/by/ $4.0 /)$.
Abstract: The floodplain areas along the Naryn River in Kyrgyzstan are essential as they hold the riparian (local) ecosystems because they provide firewood, pastureland, and areas for recreation and protection against erosion. Due to limited access to adequate, reliable, and sustainable energy services, the rural population usually derived their energy needs from multiple natural energy resources (i.e., firewood, charcoal, agricultural residues, animal dung, and wood branches). This is considered a common and predominant practice in rural Kyrgyzstan. This situation leads to a negative impact on local ecosystem services. In addition to that, the reliance on solid fuels contributes to indoor and outdoor air pollution, which is partially threatening the local ecosystem services. By contrast, the employment of renewable-based energy supply systems would substantially reduce the burden on the environment, which is mainly untapped. To integrate renewable energies, it is important to understand the energy behavior of floodplain communities. In that response, the presented article is the first attempt to capture the energy identity of the floodplain community of Kyrgyzstan based on a quantitative energy-based (on-site) household survey. Furthermore, the present research article synthesizes the driving factors that have a (direct or indirect) impact on the energy and local ecosystem services. In addition, the present article proposes a brief pathway for the sustainable energy transition. The article records the recommendation to integrate renewable energies to preserve the local ecosystems of Kyrgyzstan.

Keywords: Central Asia; ecosystem services; energy pattern; energy profiling; floodplain community; high-altitude; household survey; Kyrgyzstan; renewable energies; sustainability

\section{Introduction \\ 1.1. Background and Context}

Ecosystems offer a wide spectrum of mandatory services for the sustainable functioning of the environment, social development, economic development, and, of course, the development of the human being. Kyrgyzstan, a Central Asian country, is well known for its continental climate. The abstracted water resources (especially rivers) and their floodplains hold natural yet important (local) ecosystems. Most of the ecosystems are still in a natural state. Degembaeva et al. [1] and Lauermann et al. [2] described that such natural ecosystems provide essential services to the local population, such as firewood, grazing land recreational areas, and protection against erosion. Further to this, Karthe et al. [3] described the water resources and their management including ecosystems in Central Asia.

However, such essential ecosystems, especially in rural Kyrgyzstan, are exposed to overexploitation because people have heavily utilized the natural resources provided by 
such ecosystems to fulfil their needs [4]. Among Central Asian countries, Kyrgyzstan is the country most vulnerable to climate change. Over $60 \%$ of the rural Kyrgyz population directly depends on natural resources for their livelihoods $[5,6]$. The high reliance on firewood usage negatively impacts the riparian forests, and therefore, the local ecosystem becomes unbalanced [7]. Besides the nonsustainable exploitation of forest wood, rural floodplain communities extensively use solid fuels such as charcoal and cow dung to meet the primary needs (i.e., space heating because of the long and harsh winters) [8].

Most of the Kyrgyz building stock (especially in rural settlements) was built 30-60 years ago during the Soviet era without regard for energy efficiency. The age of the residential buildings, poor housing conditions, and the absence of proper thermal insulation result in high heat demand and low thermal comfort in rural Kyrgyz houses [8]. To meet the high domestic space heating, communities are more inclined to utilize natural resources to meet their energy needs. Naturally, the overexploitation of nonsustainable solid fuels causes indoor air pollution and outdoor pollution, resulting in health-damaging issues.

According to Brakema et al. [9], the high-altitude rural settlements in Kyrgyzstan are particularly vulnerable to Chronic Obstructive Pulmonary Disease (COPD) and significantly experience respiratory issues because of household air pollution. This pollution directly or indirectly contributes to climate change. Climate change is an imperative parameter that influences not only the environment but local ecosystems too [10,11]. It is important to highlight that the resources which ecosystems provide are limited and conventional (i.e., forest wood). The overexploitation of an ecosystem can be harmful to the local biodiversity and environment.

Li et al. [12] provided a detailed illustration of how rural energy consumption affects the environment and economy. The authors further identified that reliance on the environment places great pressure on natural resources and seriously restricts the sustainable development of the region. Hence, there is an urgent need to preserve the ecosystems of Kyrgyzstan.

The rural communities in Kyrgyzstan are less likely to connect with community services such as district heating services and hot water supply systems. As mentioned earlier, local people exploit the ecosystem/surrounding environment to meet their energy needs because they do not have access to modern energy services. By contrast, the country is blessed with plentiful renewable energy resources, mostly unexploited because of the lack of resources and infrastructure [5]. The recent theoretical development identified that locally available renewable energy resources could be employed to ensure a sustainable energy supply in Kyrgyzstan. Such a sustainable solution can indeed be helpful to reduce the burden on the local ecosystem $[13,14]$. This is how the reliance on the ecosystem and environment can be reduced [5].

\subsection{Research Objective and Contribution to Knowledge}

To integrate renewable energies to a community, it is necessary and important to understand the dynamics of the energy behavior of the floodplain community. In that regard, it is helpful to make the energy-related information about the floodplain community available to establish a sustainable energy transition through potentially present renewable energies. However, available information about floodplain communities in the context of energy behavior is explicitly insufficient and does not provide enough knowledge to map the energy identity. Furthermore, a detailed comprehensive assessment is missing about community energy consumption and energy supply patterns to understand the full picture of floodplain households and their dependency on the local ecosystem. The scant information does not provide a complete depiction to international readers about the energy-usage behavior. To address the research gaps and to contribute to the knowledge, the authors conducted detailed energy-based on-site surveys of a floodplain community in Kyrgyzstan. The authentic data collected from the household survey collect the novel and comprehensive information about the energy characteristics of the rural Kyrgyz community. The detailed outline assisted with defining the energy identity of the floodplain community. 
It can fill in as the strong base for designing the renewable energy-assisted supply system to preserve the local ecosystems.

\subsection{Outlook to the Case Study Area}

Degembaeva et al. [1] identified that floodplain areas along the Naryn River are vital as they are closely linked with the riparian ecosystems, which have a high magnitude on the life of local people. The Naryn River is one of the primary water sources of the country which originates in the Tian Shan mountains and flows across Kyrgyzstan and Uzbekistan. As one of the largest rivers (length around $700 \mathrm{~km}$ ), the Naryn River contains diverse patterns through the flow regiment. It was identified that the largest floodplain areas are located in the central part of the catchment (downstream of the Naryn city) [1]. The rural settlement Ak-Tal was selected from this catchment as the case study area. Ak-Tal is a floodplain community located around $80 \mathrm{~km}$ downstream from Naryn city, which is represented in Figure 1. Ak-Tal is a high-altitude floodplain area around $1600 \mathrm{~m}$ above sea level and situated between the Naryn River in the North and the mountain ranges in the South.

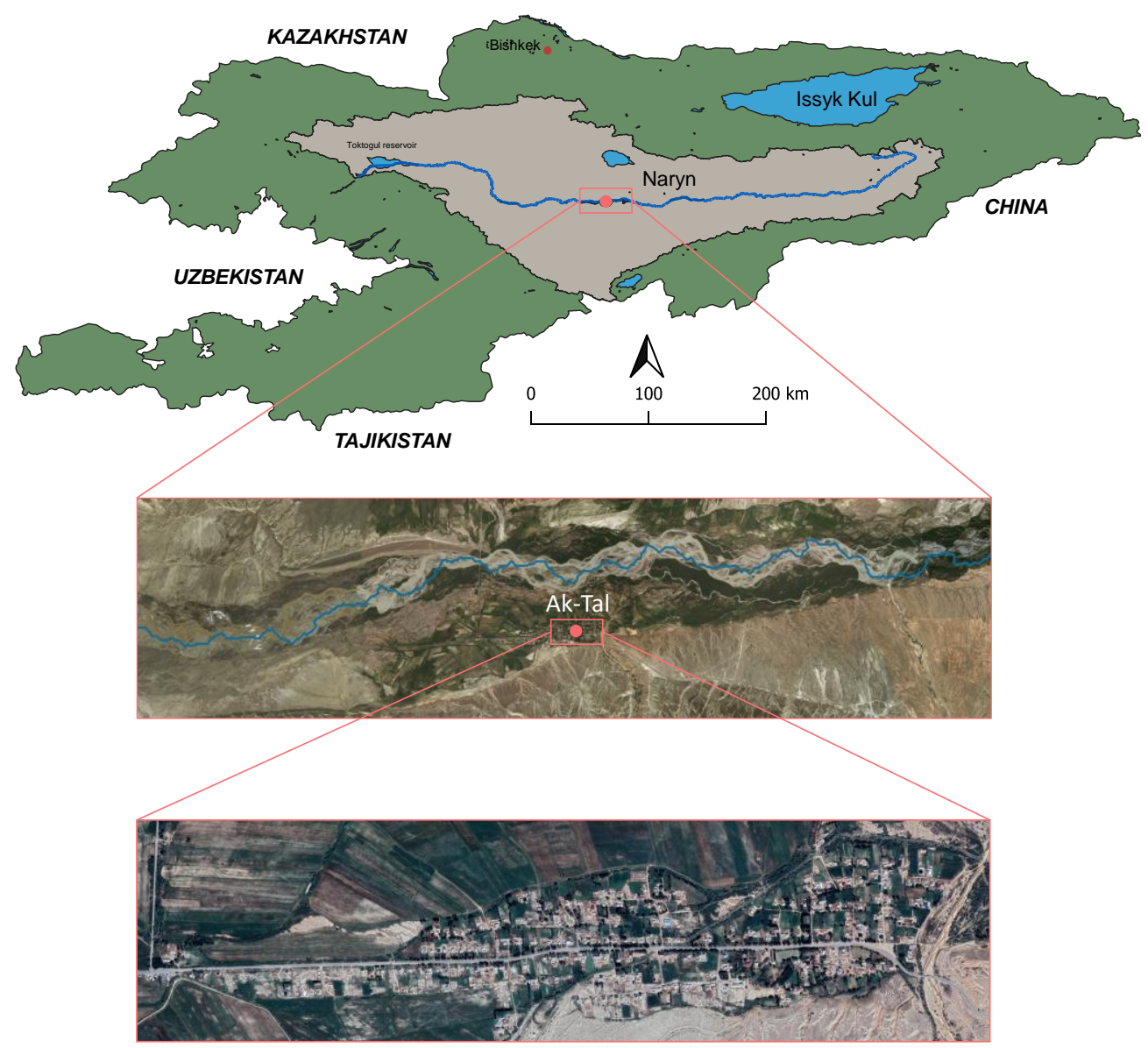

Figure 1. The location of the Naryn River catchment and the case study area: Ak-Tal community (floodplain area) [source: author, base map: Google Earth].

The presented research article quantifies the energy identity of a typical floodplain community (in this case, Ak-Tal) by performing a quantitative household survey. The findings from the household survey helped to derive the energy characteristic which can serve as a base for the sustainable energy transition in Kyrgyzstan to preserve the local ecosystems. 


\section{Materials and Methods}

\subsection{Survey Design}

Rural communities in Kyrgyzstan are mainly formulated with residential houses. Hence, it is necessary to understand the residential energy behavior. The amount and type of energy used in residential houses in the community are mainly associated with the housing conditions, building envelope, and building characteristics. Furthermore, the energy carrier, energy devices, and user behavior are also the parameters that are not only associated with energy consumption but also with the ecosystem, as the majority of the households directly rely on the environment. To comprehensively realize the energy consumption and energy usage behavior of households in the floodplain community, the question form for the quantitative household survey was designed with energy-related content and attention displayed in Figure 2. The survey content includes detailed questions about building information, occupant behavior, energy information, and thermal comfort.

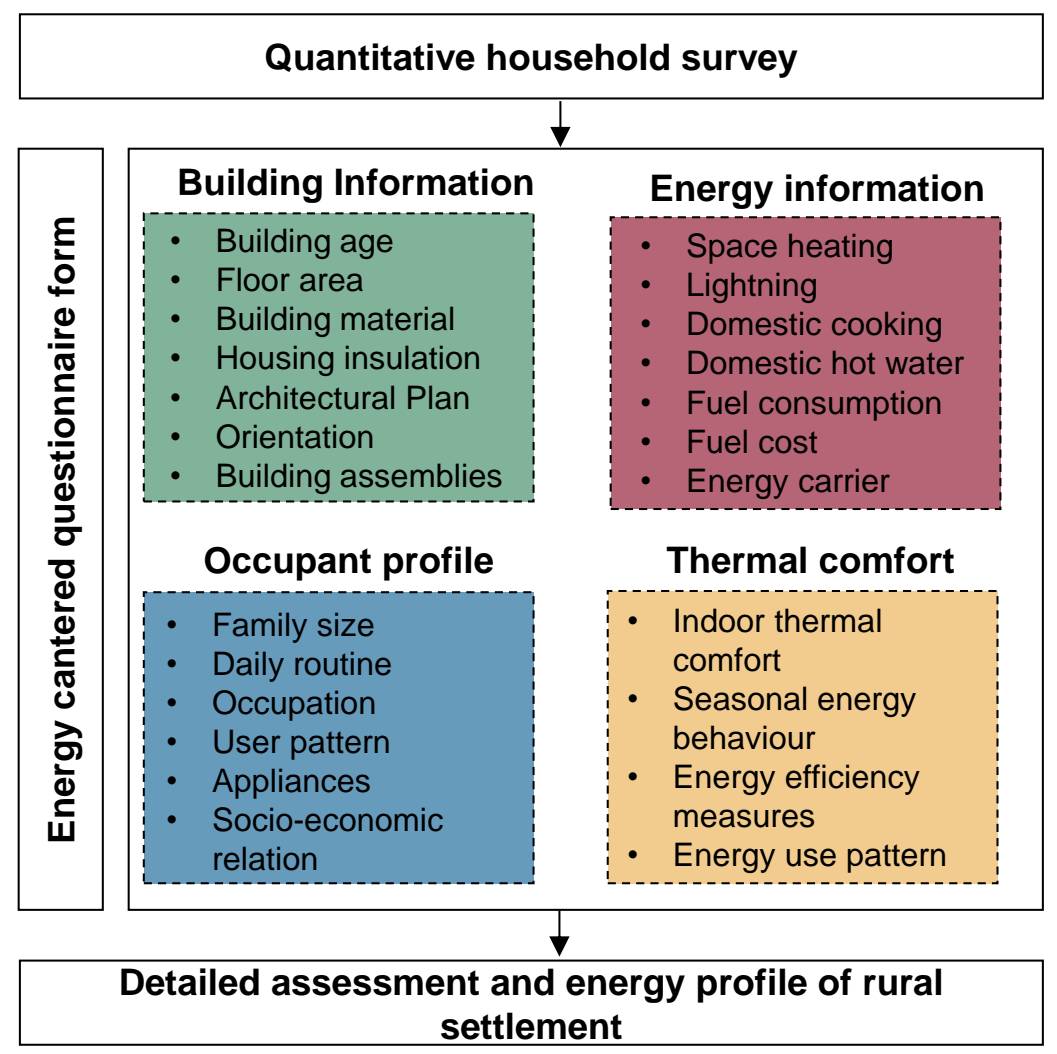

Figure 2. Research design and survey coverage of the presented work.

The survey was performed in the Kyrgyz language to avoid linguistic barriers. Later, the survey results were translated to English for further evaluation. To analyze the energy consumption of rural Kyrgyz households, the developed questionnaire appropriately included various aspects of energy supply. For example, respondents were asked to estimate their fuel consumption per year (including coal, firewood, and cow dung) and were asked specific questions about daily routines to derive usage profiles. In addition, the questionnaires were used to collect general building information as well as data on the housing situation, domestic space heating, hot water, and electricity supply. During the on-site stay in the middle of winter, the performed survey was able to take a closer look at local household conditions and the ground reality. Conversations with the residents during the interviews provided both fundamental insights into their views on energy supply and consumption and their use and perception of the energy. 


\subsection{Sample Size Calculation and Selection}

Ak-Tal is a community where a total of 234 households are positioned on both sides of the country's main road, and it is home to around 1500 people. Since it was a qualitative household survey, the sample size and sample selection were calculated based on the total households. To determine the same size, the following equation was used [15].

$$
\text { Sample size }=\frac{\frac{Z^{2} x p(1-p)}{e^{2}}}{1+\left(\frac{Z^{2} x p(1-p)}{e^{2} N}\right)}
$$

where

$Z$ = Confidence level (standard normal distribution);

$N=$ Population size (total number of households $=234$ );

$e=$ Margin of error;

$p=$ Value of probability.

The calculated sample size was 35 , and that was the satisfactory sample size with a confidence level of $80 \%$ and a margin of error of $10 \%$. However, to cover more households, the sample size was rounded to 40 . The survey quality was guaranteed and maintained because questions were asked in the local language (Kyrgyz), and answers were recorded in the Kyrgyz language to avoid miscommunication. Figure 3 displays the interviewed houses during the Ak-Tal household survey.

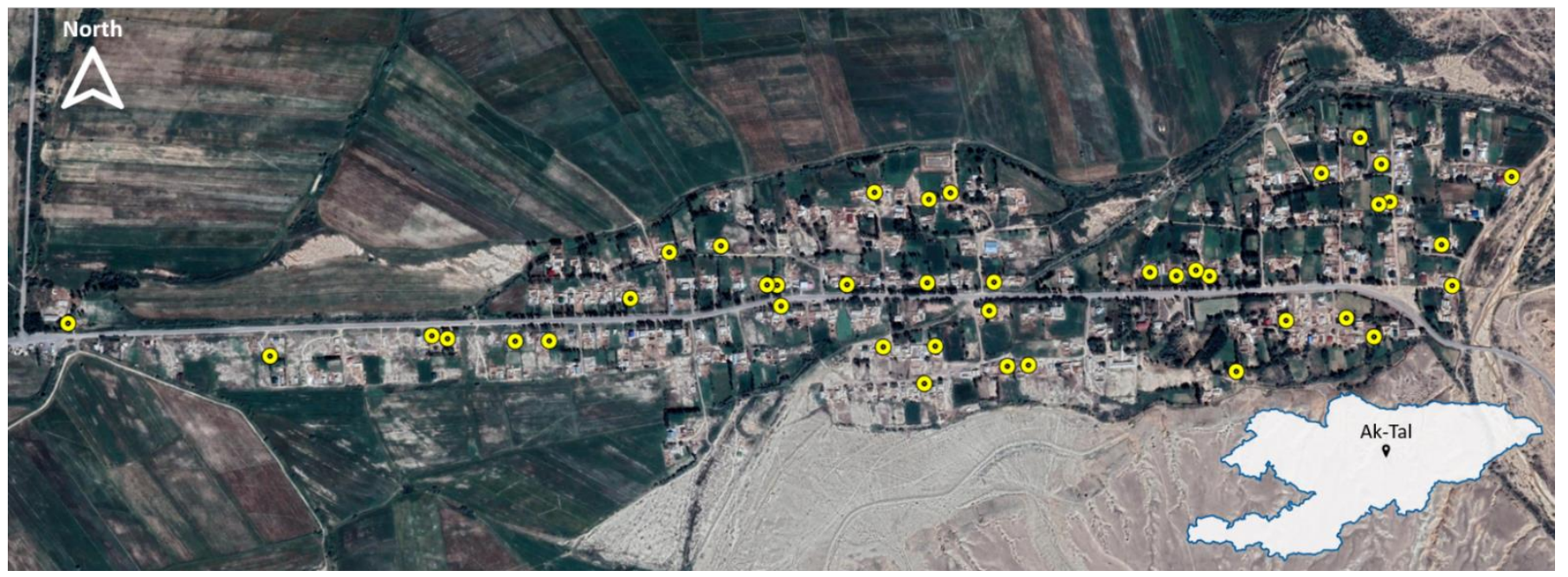

Figure 3. Interviewed houses (sample size $N=40$ ) in the Ak-Tal community [source: author, base map: Google Earth].

To cover each corner of the community, the sample was selected thoroughly based on the random sampling method. The survey results and detailed assessment are presented in the following chapter. All the described data are based on the survey, visual/personal observation, and conversation with the local people.

\section{Profile of the Studied Households}

The communities located in the mountains regions of Kyrgyzstan typically hold a lower population density than urban areas and are disconnected from the urban centers. The mountain people reside in difficult high-altitude terrain, far from economic centers, and exert over the policies and decisions that influence their living standards. Therefore, these societies face a significant challenge in community development because of poor infrastructure and rural-urban communication channels. The majority of the Kyrgyz area is symbolized by high-altitude background (average elevation $3000 \mathrm{~m}$ above sea level) and is covered by an extended range of mountains. The geographical condition results in the cold climatic zone in Kyrgyzstan. The winter temperatures range from about $-4{ }^{\circ} \mathrm{C}$ to $-6{ }^{\circ} \mathrm{C}$ 
in the lowlands and from $-25^{\circ} \mathrm{C}$ to $-30{ }^{\circ} \mathrm{C}$ in the mountainous. Hence, high-altitude settlements with long periods of cold weather conditions face additional challenges because most of the energy is used for house heating rather than cooking [5]. Figure 4 represents the Ak-Tal community and house arrangement.

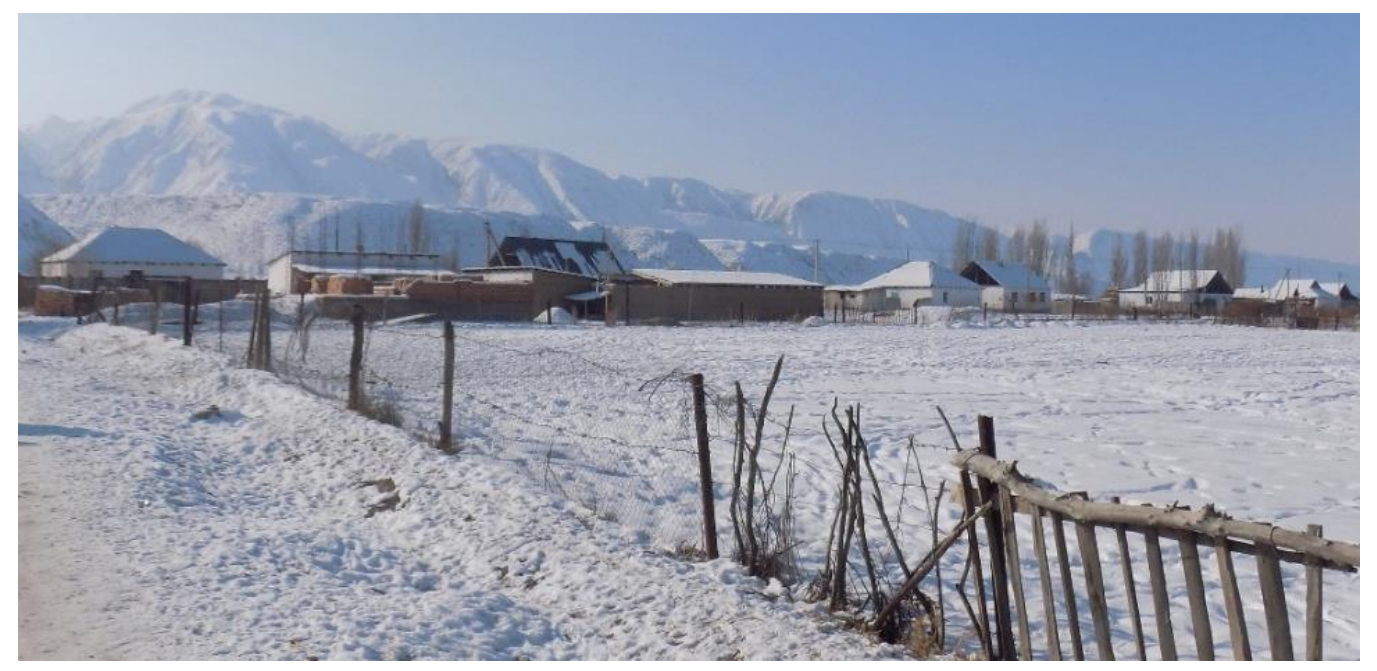

Figure 4. Ak-Tal community during wintertime [source: author].

Many rural communal households, especially in mountainous areas, do not have a permanent source of income because job opportunities are often scarce. Hence, almost all households are engaged in agricultural activities/animal husbandry. However, harsh and long winters and collected snowfall on agricultural land cause the agricultural activities to slow down. Hence, during the winter season, it is not easy to generate a constant income for rural households.

\subsection{Occupant Behavior}

It was identified during the household survey that most households consist from around four to six people living together in a traditional rural house. Generally, rural families stay together as a big family - two adults and their children and grandparents. The interviews identified the general routine of the rural household. The youngest son is responsible for taking care of his aging parents. Kyrgyz women are mainly responsible for household tasks such as cooking, livestock feeding, and watering, fueling solid fuels to heating stoves, and baking, while a Kyrgyz man is typically the financial head of the house. Men and children go to work and school, respectively, in the early morning. Based on the daily routine observations of various houses, a generalized occupancy profile for rural Kyrgyz houses was developed, which is shown in Figure 5. The profile is presented in a fraction of present persons in the house at various timeslot of the day.

\begin{tabular}{|c|c|c|c|c|c|c|c|c|c|c|c|c|c|c|c|c|c|c|c|c|c|c|c|c|}
\hline Hours & $\mathbf{0}$ & $\mathbf{1}$ & $\mathbf{2}$ & $\mathbf{3}$ & $\mathbf{4}$ & $\mathbf{5}$ & $\mathbf{6}$ & $\mathbf{7}$ & $\mathbf{8}$ & $\mathbf{9}$ & $\mathbf{1 0}$ & $\mathbf{1 1}$ & $\mathbf{1 2}$ & $\mathbf{1 3}$ & $\mathbf{1 4}$ & $\mathbf{1 5}$ & $\mathbf{1 6}$ & $\mathbf{1 7}$ & $\mathbf{1 8}$ & $\mathbf{1 9}$ & $\mathbf{2 0}$ & $\mathbf{2 1}$ & $\mathbf{2 2}$ & $\mathbf{2 3}$ \\
\hline Night & 1 & 1 & 1 & 1 & 1 & 1 & & & & & & & & & & & & & & & & 1 & 1 & 1 \\
\hline Morning & & & & & & & 0.7 & 0.7 & 0.3 & 0.3 & 0.2 & 0.4 & 0.7 & & & & & & & & & & & \\
\hline Afternoon & & & & & & & & & & & & & 0.6 & 0.3 & 0.5 & 0.5 & & & & & & & \\
\hline Evening & & & & & & & & & & & & & & & & & & 0.4 & 0.7 & 0.7 & 1 & & \\
\hline
\end{tabular}

Figure 5. Generalized daily household occupancy pattern in a fraction of present persons (1 is a full occupancy, 0.5 is half of the total occupancy). 


\subsection{Building Characteristics}

Almost all the Kyrgyz housing stock was constructed during the Soviet period (during 1950-1980) with earthen materials (i.e., adobe, mud, clay, soil, etc.) without any energy efficiency measures. During those years, energy cost was low/negligible, and therefore, residential buildings did not consider any energy efficiency measures to improve the thermal performance of houses. This is rightly associated with the case study area Ak-Tal community.

All the houses in the Ak-Tal community are self-built and single-family houses with a single floor. More than $80 \%$ of Ak-Tal households are built with earthen materials. Out of all earthen materials, clay-straw bricks are the most common and favorite building construction materials because this technique is well known, and the knowledge is available locally. Generally, families assist each other with house construction in rural Kyrgyzstan. Therefore, the housing profile in most rural communities is relatively homogeneous. Because of the independent house construction, the building codes are seldom considered while constructing the rural houses [8].

An average house in Ak-Tal is constructed with clay-straw bricks (mixture of clay and straw and mold in brick form). In the majority of the cases, the bricks are self-made and then left under the sun for natural drying (generally $15 \mathrm{~cm} \times 15 \mathrm{~cm} \times 30 \mathrm{~cm}$ but varies by region). Besides clay-straw bricks, soil wall (with the rammed earth) is widely accepted for house construction because it does not require any mixing process.

The majority of the houses in the community are private households. Besides the private households, the community has several public buildings (around seven) such as kindergarten, local self-governance, school, etc. More than $50 \%$ of the building stock was built 30 years ago. Figure 6a represents building construction materials of the interviewed households, and Figure $6 \mathrm{~b}$ displays the age band (house construction age) of the houses. More than $90 \%$ of household respondents said that they did not apply any insulation measures while constructing their houses.

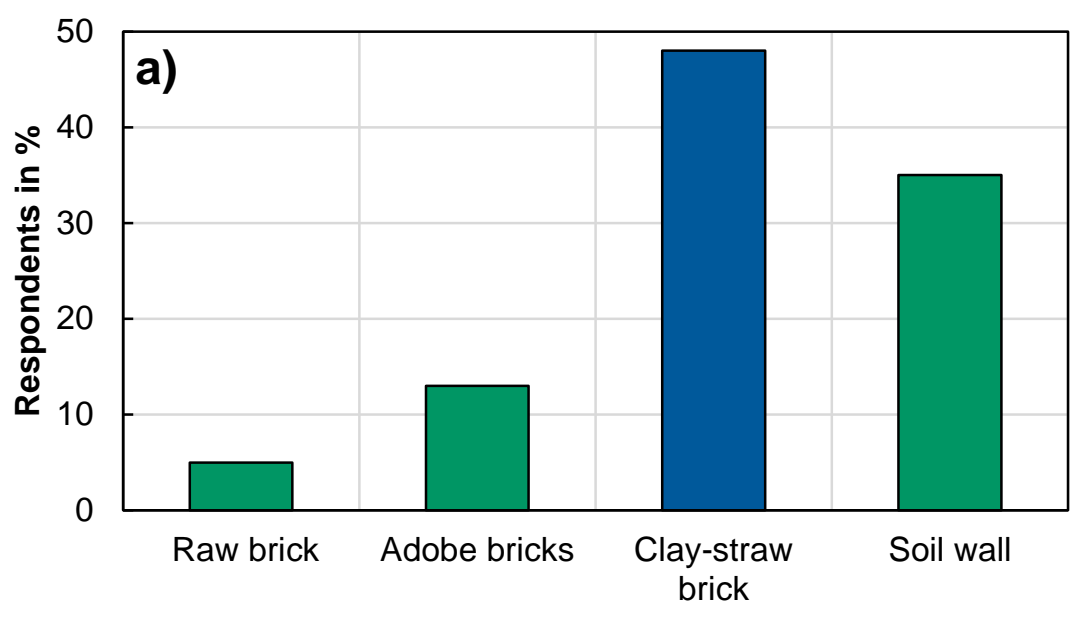

Construction material of wall

b)

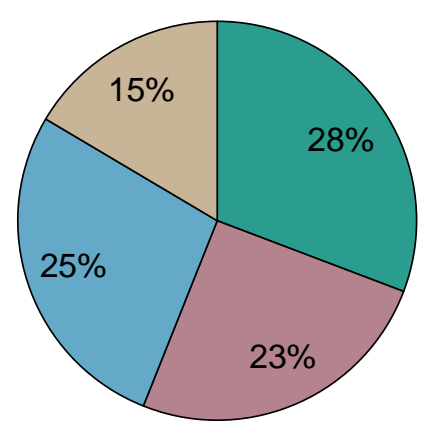

$\square 1$ to 20

$\square 21$ to 40

$\square 41$ to 60

$\square$ Not answered

Figure 6. (a) Building construction material and (b) the age band of houses $(N=40)$.

The average floor area of the household in Ak-Tal ranges between 90 and $110 \mathrm{~m}^{2}$. The houses are generally large and consist of four to five rooms (more than 70\%) which contain an open room to store shoes, winter clothes, and/or for miscellaneous purposes, kitchen, living room, and bedrooms. It was observed that the houses which were constructed in the last 10 years hold more floor area (i.e., $125 \mathrm{~m}^{2}$ ) as compared to the average house because of the improved living standards. Figure 7 represents the recorded data. 

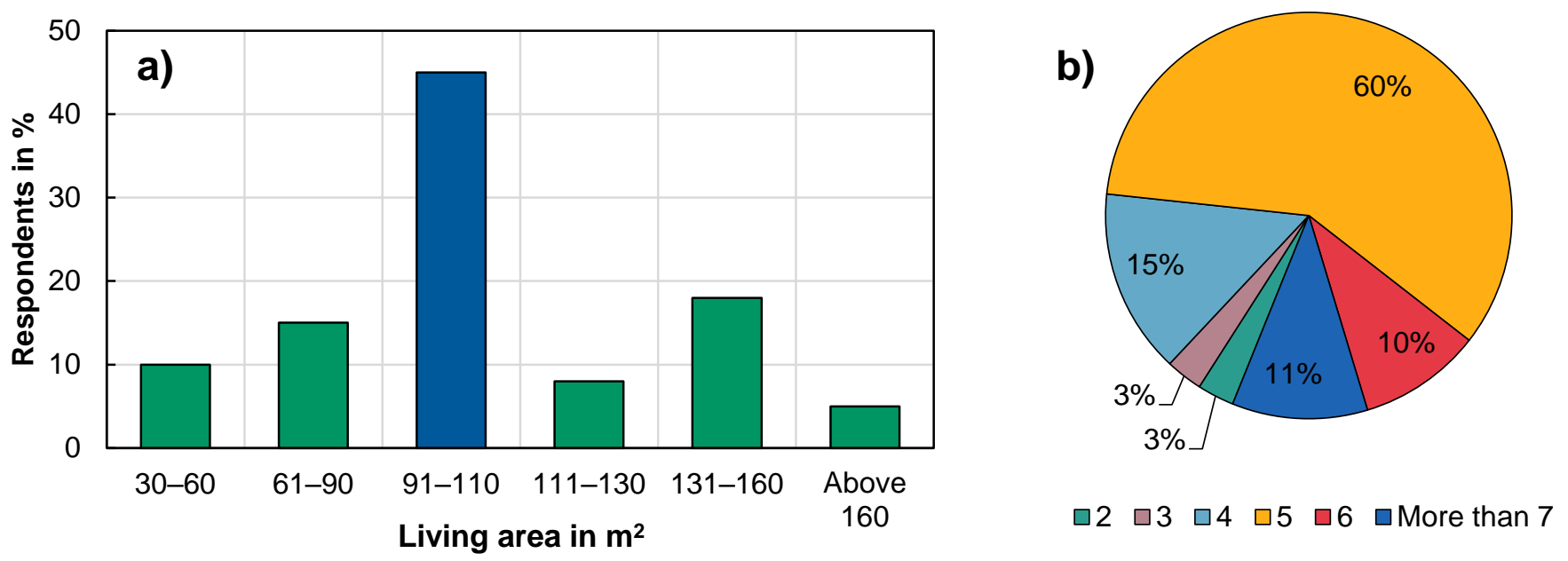

Figure 7. (a) Distribution of household floor area and (b) number of rooms $(N=40)$.

\subsection{Building Construction Technique}

From the household survey questions related to the building envelope characteristic and visual observation, the typical housing profile was derived. This housing profile can be transferable to any other rural/neighboring communities as the rural areas in Kyrgyzstan look uniform.

- Foundation and Floor: A typical rural house has an earthen floor with a layer of natural stone and/or concrete for the stability of the foundation as a first layer. Generally, the floor has a thickness of $0.25-0.50 \mathrm{~m}$ without thermal insulation (in the majority of the cases).

- Walls: As mentioned above, walls are constructed with soil-based materials without insulation materials. To cope with the cold climate, the walls are thicker, and the thickness of the wall ranges between 0.35 and $0.50 \mathrm{~m}$. To protect and give a finished look to the soil-based walls, a thin layer of plaster is applied. It is a predominant practice to apply clay plaster (with a thickness of $2-3 \mathrm{~cm}$ ).

- Ceiling: The construction of the ceiling is most similar to the floor. The wooden (timber)-beam ceiling is the most common in the Ak-Tal community. The ceiling contains wooden beams placed on the walls and wooden plank/boards on the top. To cover the wooden planks, a thick layer of clay and/or slag is applied for protection.

- Roof: The wooden beam ceiling is usually covered by an open gable roof. More than $50 \%$ of households do not have closed roofs because of a lack of knowledge and income. However, this is a common practice in Kyrgyzstan. The houses which have a closed gable roof are either open from one end or have leakages. Naturally, the open space induces a considerable amount of heat loss during windy and cold days.

- Windows: The windows are generally double-glazed; however, the frame materials are varied across the community. Almost $40 \%$ of households have PVC-based windows. Around $33 \%$ of houses are equipped with wooden-framed windows, mostly crackly and exposed to air leakages. The rest of the houses have mixed (wooden and PVC) windows installed.

Table 1 portrays the detailed illustration of the building envelopes constructions with real on-site images. 
Table 1. The construction process of individual building features [source: author].

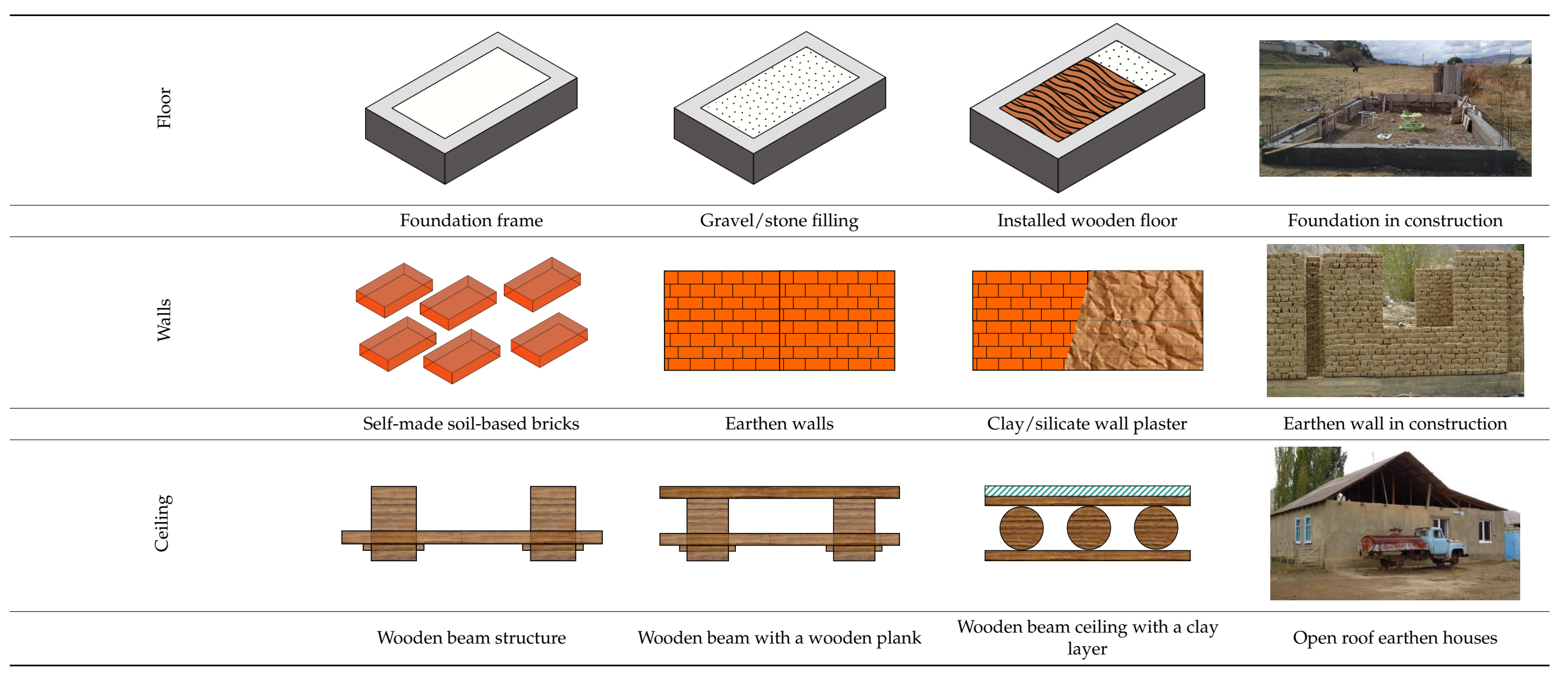




\subsection{Thermal Comfort}

As discussed above, buildings in Ak-Tal are mostly built with natural materials without proper building construction techniques and energy efficiency measures. Hence, houses are the key energy consumer as they tend to have high heat demands. Mehta et al. [8] identified that the (heat) energy consumption of rural traditional Kyrgyz houses ranges between 290 and $320 \mathrm{kWh} / \mathrm{m}^{2}$. Furthermore, UNDP [16] also mentioned that energy use in Kyrgyzstan varies between 320 and $690 \mathrm{kWh} / \mathrm{m}^{2}$ per year, which is almost 3-5 times higher than European buildings.

The building thermography is one of the most convenient ways to diagnose and monitor the heat transfer of a building. To identify the heat transfer of rural Kyrgyz houses, a thermography analysis was performed for the presented research work. The thermal image of a rural Kyrgyz house is exemplarily shown in Figure 8a, which illustrates the heat losses through the old and uninsulated building envelope. Figure $8 \mathrm{~b}$ represents the thermal image of the newly built house in Ak-Tal, which has an improved building envelope installed with PVC windows.

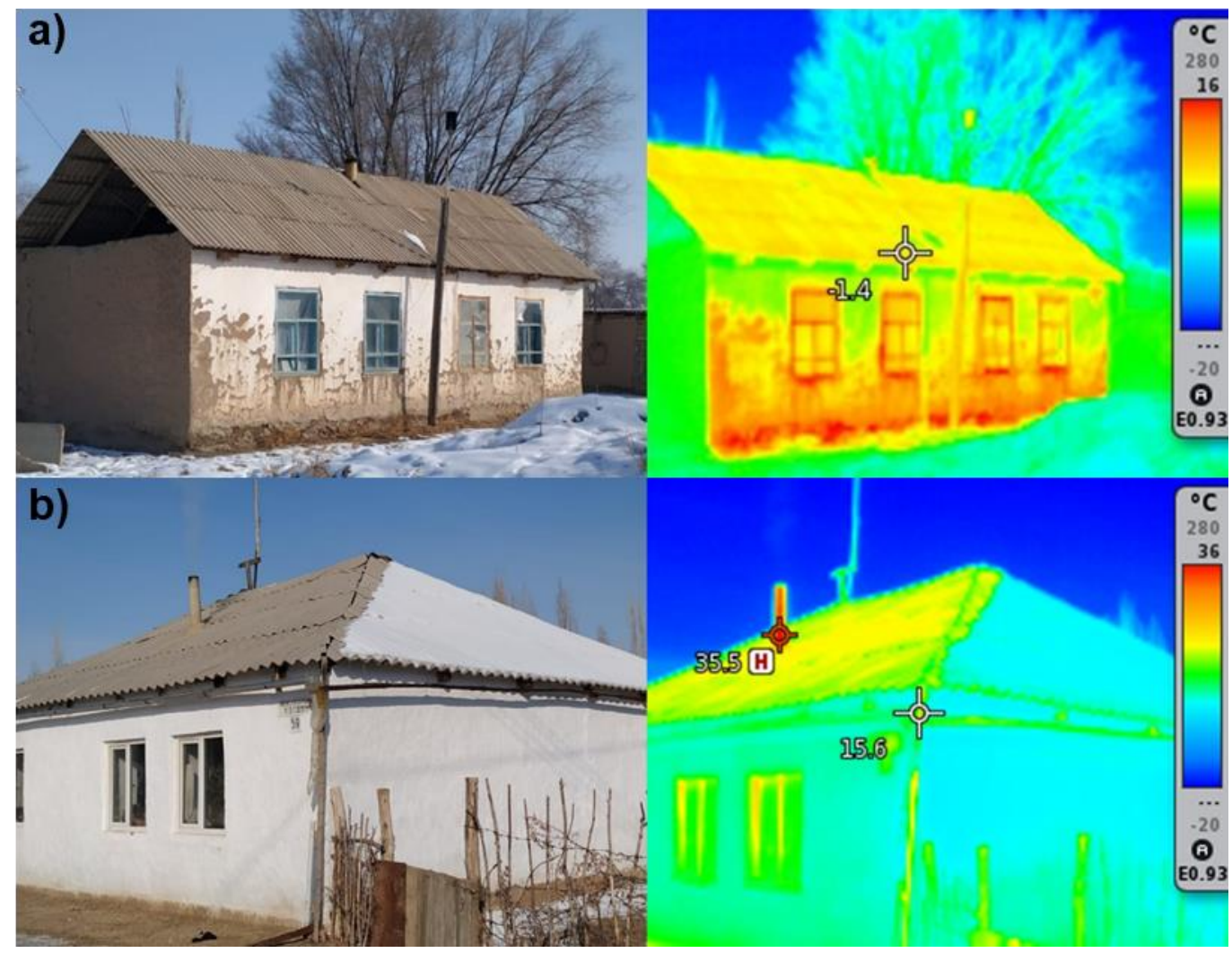

Figure 8. Thermal images of different Kyrgyz houses in the Ak-Tal region during the heating season (February 2020) (a) the old and uninsulated building, (b) newly built house [source: author].

It can be seen that the earthen houses need a high amount of energy to maintain thermal comfort inside the house. The current deteriorated and outdated building infrastructure conditions indicate a massive potential for energy savings in Kyrgyzstan. According to the Mountain Societies Research Institute, "up to almost $60 \%$ of heat losses can be saved by introducing the proper thermal insulation measures to rural buildings" [17]. Furthermore, Boronbaev [18] estimated that rural Kyrgyz houses could diminish energy use by around $70 \%$ by suitable sections of building materials, planning, thermal insulation, and appropriate building construction techniques.

Because uninsulated houses, open roofs, and leaky windows are the key players acting as thermal leakage, the indoor temperature drops down and reduces the thermal comfort inside the house. To improve indoor thermal conditions, households use thick wool carpets 
during the winter season. The thick carpet can work as an additional building layer and help to prevent the coming cold from the outside. Around $50 \%$ of the household responded that they cover windows. By contrast, around $25 \%$ of households used to protect walls with carpet. Figure 9 illustrates the detailed data as well as the pictures of buildings where the carpets are visible. This is a common practice followed in Kyrgyzstan during the wintertime.
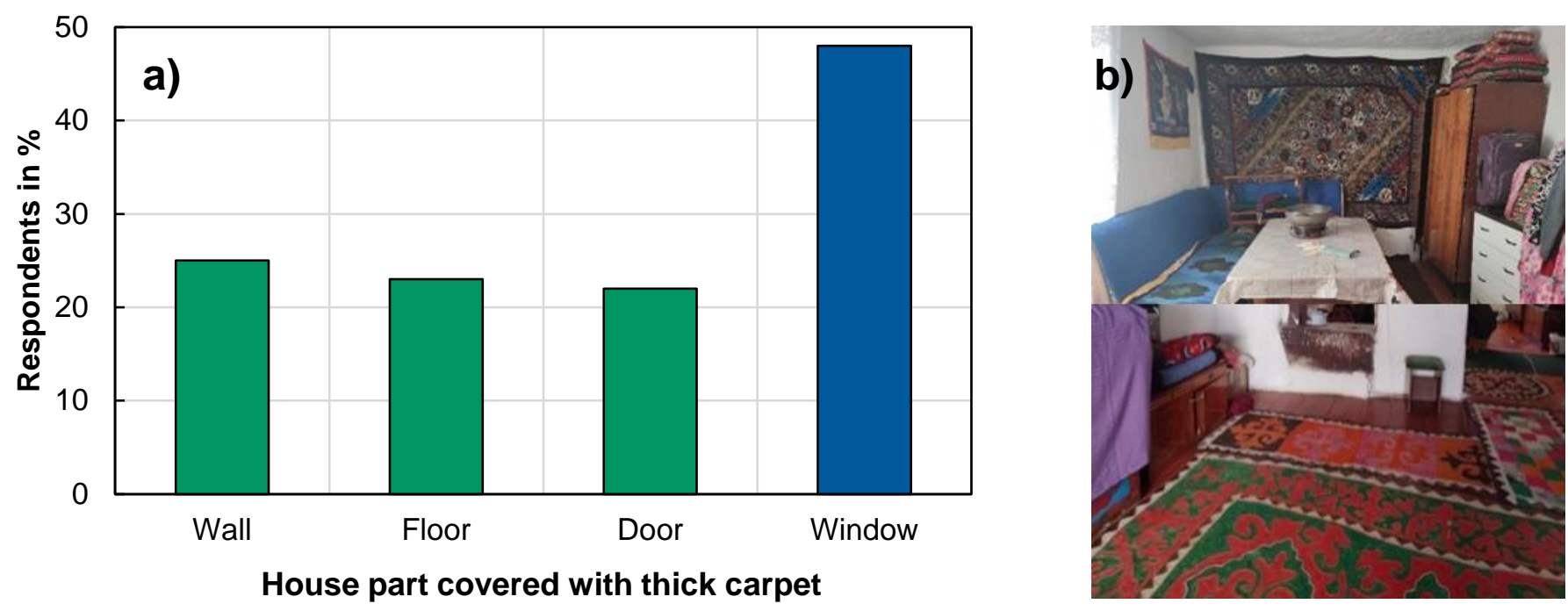

Figure 9. (a) House part covered with the carpet and (b) carpet in the traditional rural Kyrgyz house $(N=40)$.

Indoor comfort/satisfaction with living conditions is a key indicator to understanding the household behavior and views on the existing building condition. Despite the terminated and poor energy efficiency buildings, more than $75 \%$ of households reported that they are satisfied with the current building conditions. While around $65 \%$ of households responded that they are satisfied with the indoor thermal temperature, overall, about $10 \%$ of respondents were dissatisfied with the housing, window, and door conditions. Table 2 summarizes the responses of the household on the indoor comfort and satisfaction level.

Table 2. Satisfaction of housing conditions $(N=40)$.

\begin{tabular}{cccc}
\hline $\begin{array}{c}\text { Satisfaction with Indoor } \\
\text { House Temperature }\end{array}$ & $\begin{array}{c}\text { Satisfaction with Current } \\
\text { Housing Conditions }\end{array}$ & $\begin{array}{c}\text { Satisfaction with Windows } \\
\text { Condition }\end{array}$ & $\begin{array}{c}\text { Satisfaction with Door } \\
\text { Condition }\end{array}$ \\
\hline Fully satisfied; & Somewhat satisfied;
\end{tabular}

However, even though with the high level of satisfaction with thermal comfort, when households were asked about their plans to renovate their homes, around $80 \%$ of households said they would like to renovate their house in upcoming years (until 2030) based on the financial conditions in most of the cases. In reality, the lack of financial resources and knowledge prevents rural Kyrgyz people from improving the energy efficiency of their homes. 


\subsection{Building Energy Use and Consumption}

\subsubsection{Electricity}

Because of the legacy of Soviet infrastructure and the strength of hydropower plants, access to electricity through the national grid is common in Kyrgyzstan ( 99\%), including urban and rural households. In that context, all the houses of the case study area are electrified. More than $90 \%$ of the electricity in Kyrgyzstan is produced by various hydropower plants [5]. However, during the freezing winter, the water flow is reduced, leading to limited electricity production. Because of urbanization and high population density, priority is given to urban areas to meet the increased electricity demand in the wintertime. Due to the isolated locations and low population density, rural areas are left out from the reliable electricity supply. Around $60 \%$ of these rural households stated that they experience voltage fluctuation/cut-off in electricity supply in winter. Despite the lowest and non-cost-effective electricity tariff of $0.01 \mathrm{USD} / \mathrm{kWh}$, more than $20 \%$ of respondents reported that electricity is too expensive for them. Hence, the current electricity access is neither reliable nor affordable for house heating. Only $10 \%$ of the local population use electricity (i.e., electric radiator) for house heating as a backup/support to the traditional heating system.

It was assessed from the household survey that households who have stable income sources use electric radiators for heating (as a support to the traditional heating system). When answering the question of the reason for not using electricity for heating, the majority of the households stated that they are happy with the traditional heating stoves. Hence, it can be comprehended that rural people are inclined more towards the traditional approach. Most electricity is used for household purposes such as an electric stove, hot water with an electric kettle (for tea preparation), a washing machine, refrigerator, and television. Figure 10 displays the electrical appliances identified during the household survey.

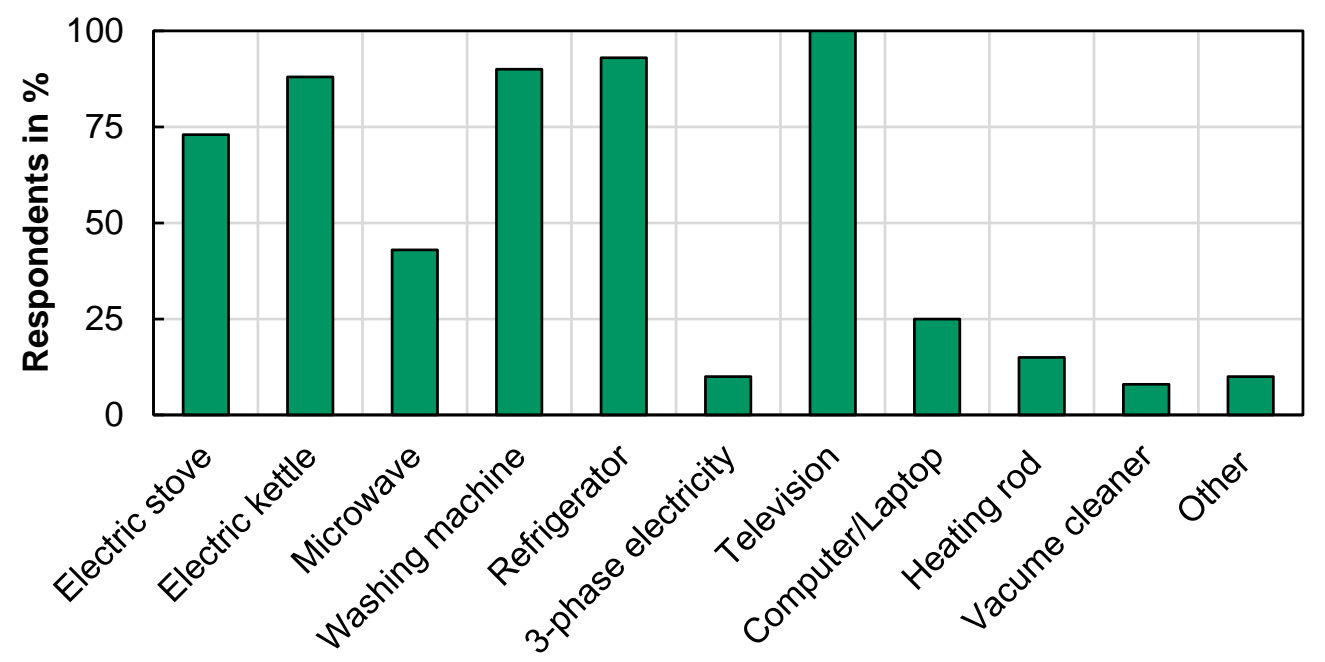

\section{Electrical appliances}

Figure 10. List of electrical appliances $(N=40)$.

The electricity costs 0.7 som for the first $700 \mathrm{kWh}$ per month, after that the cost is increased to $2.16 \mathrm{som} / \mathrm{kWh}$ (som is a Kyrgyz currency (KGS), 1 som $=0.012$ euro in February 2020). During the wintertime, because more hot water is required for cooking and livestock, it was observed that winter electricity consumption was higher as compared to the summer. Figure 11 illustrates the generalized seasonal electricity consumption and electricity expenditure of the households. 

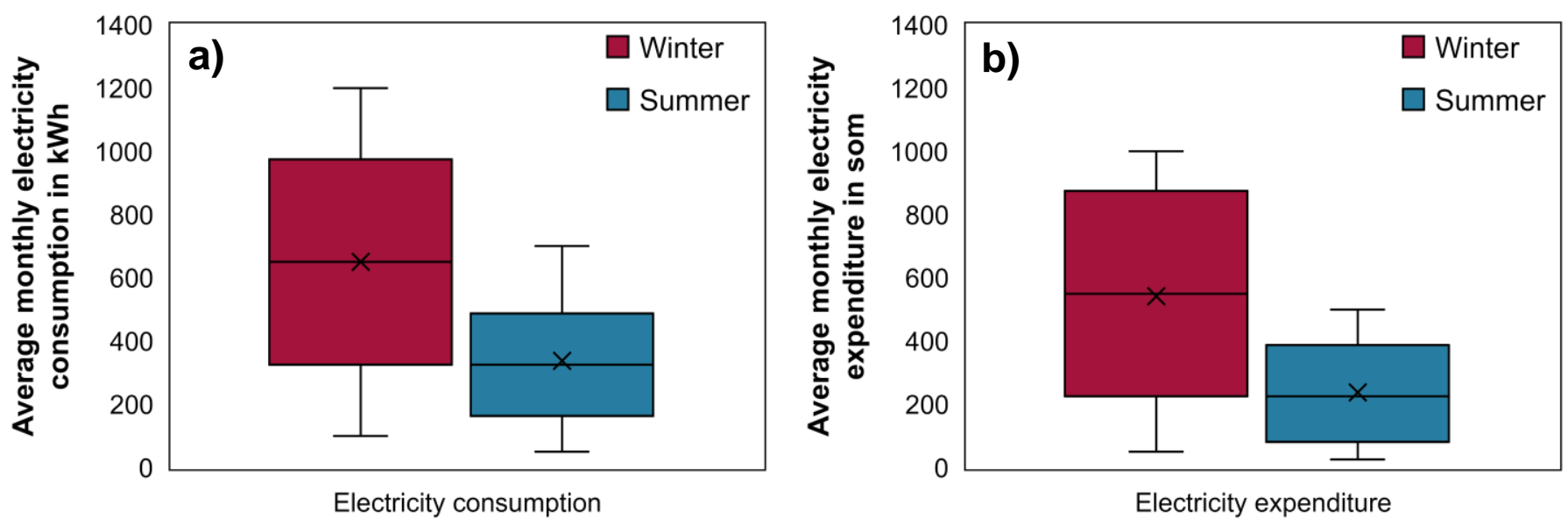

Figure 11. Average monthly electricity consumption and expenditure classified according to season (a) Seasonal electricity consumption and (b) seasonal electricity expenditure.

\subsubsection{Space Heating and Heating Fuels}

Longer heating periods and poor thermal insulation of the rural houses promote high consumption of heating fuel to maintain a pleasant temperature inside the village homes. Almost all the houses have long relied on solid fuel-fired traditional heating stoves. Figure 12 represents the characterization of existing space heating systems in the Ak-Tal community.

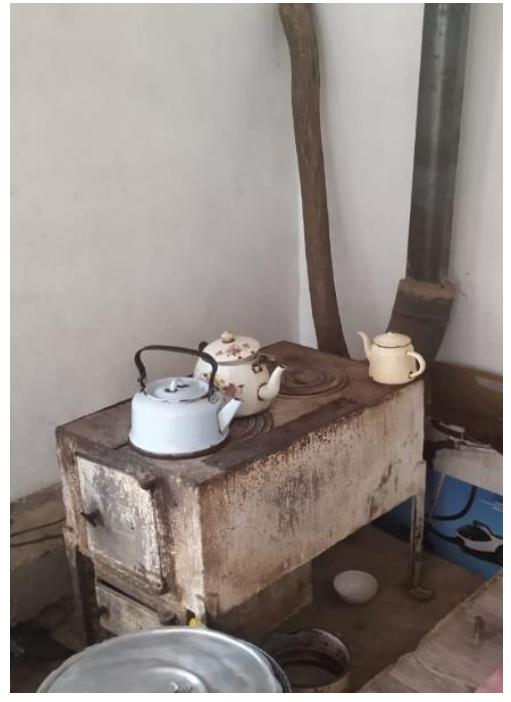

Stove placed in a corner used by $33 \%$ of household

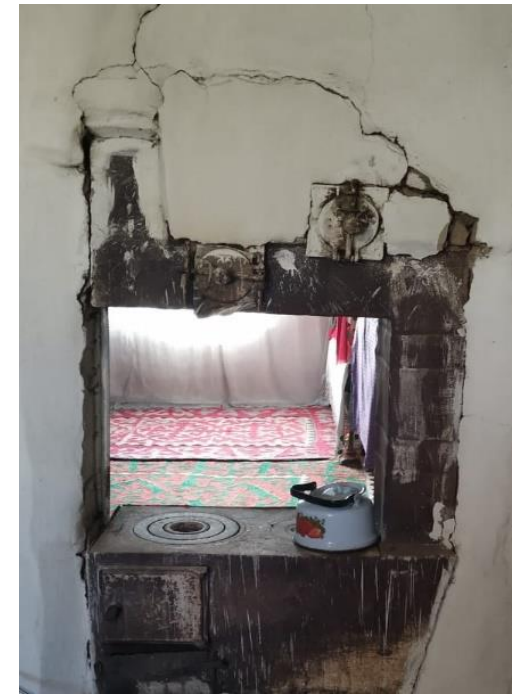

Stove placed between two walls used by $40 \%$ of household

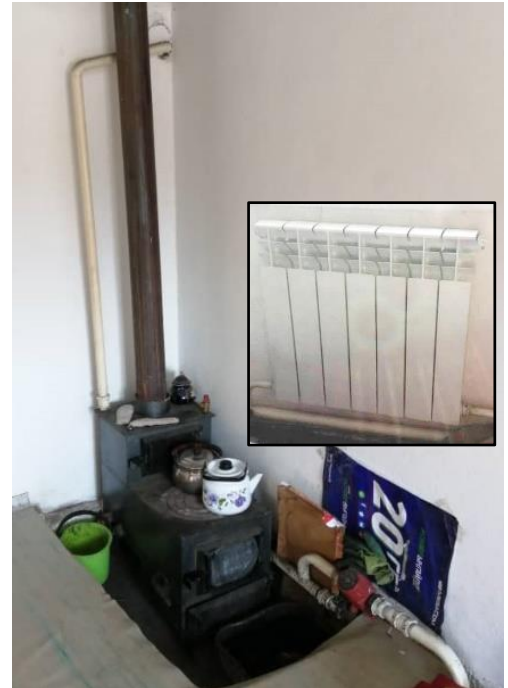

Stove with radiator heat distribution system used by $27 \%$ of household

Figure 12. Characterization of existing space heating systems fueled by solid fuels $(N=40)$.

However, the heating devices and methods to maintain thermal comfort in the house vary from household to household. The survey results show that a traditional stove without any hydraulic is the most common installation to heat the house. As most of the rural houses are not connected with the central water distribution system, they do not have an in-house hydraulic setup. By contrast, the (high-income) households who are equipped with hydraulics would have installed the radiator-based water pipe heating system. In sporadic cases, it was observed that the eclectic radiators were in use for house heating only as an additional heating source. Table 3 explains the brief description of various heating systems in use. 
Table 3. Description of house heating system used in Ak-Tal/rural Kyrgyzstan.

\begin{tabular}{ll}
\hline & $\begin{array}{l}\text { This stove is placed in the corner of the room } \\
\text { which the household would like to heat up. } \\
\text { Naturally, the heating effect can be stimulated } \\
\text { in the room where the stove is placed. There is } \\
\text { a small opening to fuel the solid fuels in front. } \\
\text { In addition, these stoves are equipped with } \\
\text { heating plates on the top to cook at the same } \\
\text { time. }\end{array}$ \\
$\begin{array}{l}\text { This is also a common heating solution and is } \\
\text { installed between two walls of the house. This } \\
\text { is convenient for heating the two rooms } \\
\text { simultaneously. This stove is also used for } \\
\text { cooking in the wintertime. }\end{array}$ \\
$\begin{array}{l}\text { This stove is assisted by an integrated heating } \\
\text { cycle through the hydraulic system. The heat is } \\
\text { distributed in the form of hot water with } \\
\text { radiators in the rooms where it is required. The } \\
\text { cold-water tank is generally placed over the } \\
\text { roof, and with the help of a thermosiphon } \\
\text { pump, water is circulated. Water flows to the } \\
\text { stove coil/jacket where the temperature is } \\
\text { raised, and later, it flows through the radiator } \\
\text { and releases the heat by convection. Cold } \\
\text { water travels back through the return pipes to } \\
\text { the stove, and the heating cycle restarts. }\end{array}$ \\
Stove with a water pipe system
\end{tabular}

All abovementioned traditional heating stoves are usually operated by solid fuels such as raw coal, firewood, wood branches, cow dung, and self-grown trees. The long heating period in a combination of low thermal insulation properties houses results in high consumption of heating fuel to maintain thermal comfort inside the house. However, because of high heat demand, house heating is an expensive task as it requires a considerable amount of heating fuels. To save money on heating fuels, rural households are used to occupying only one room for heating and closing down the rest of the house. More than $50 \%$ of households reported that they heat only the living space (2-3 rooms) in winter to save heating expenditure. Almost $65 \%$ of households limit the heating space by closing the door to the not heated rooms.

The household survey identified that coal is the most popular type of heating fuel and is used by all households (100\%). While around $70 \%$ of households use firewood, almost $67 \%$ of households utilize cow dung. It was assessed that during the winter period (from October to March), based on the availability of heating fuels and financial capabilities, households would like to use the heating fuel in combination to maintain thermal comfort inside the house. It was calculated that the average rural family needs to employ 2-6 tons of coal (cost $~ 50-250 €$ ), 1.5-3 $\mathrm{m}^{3}$ of firewood (cost $~ 5-30 €$ ), and 1-2 truckloads of cow dung (most of the time self-prepared, but in case they outsource, it costs $\sim 5-10 €$ ) for house heating. Figure 13 portrays heating fuel expenditure.

The traditional heating stoves are operated with low thermal efficiency. In that regard, almost $70 \%$ of the households responded that their heating stoves emit ash particles inside the house and create indoor air pollution. In addition to this, more than $30 \%$ of households reported health issues because of indoor air pollution (i.e., breathing problems, lung problems, and asthma). 


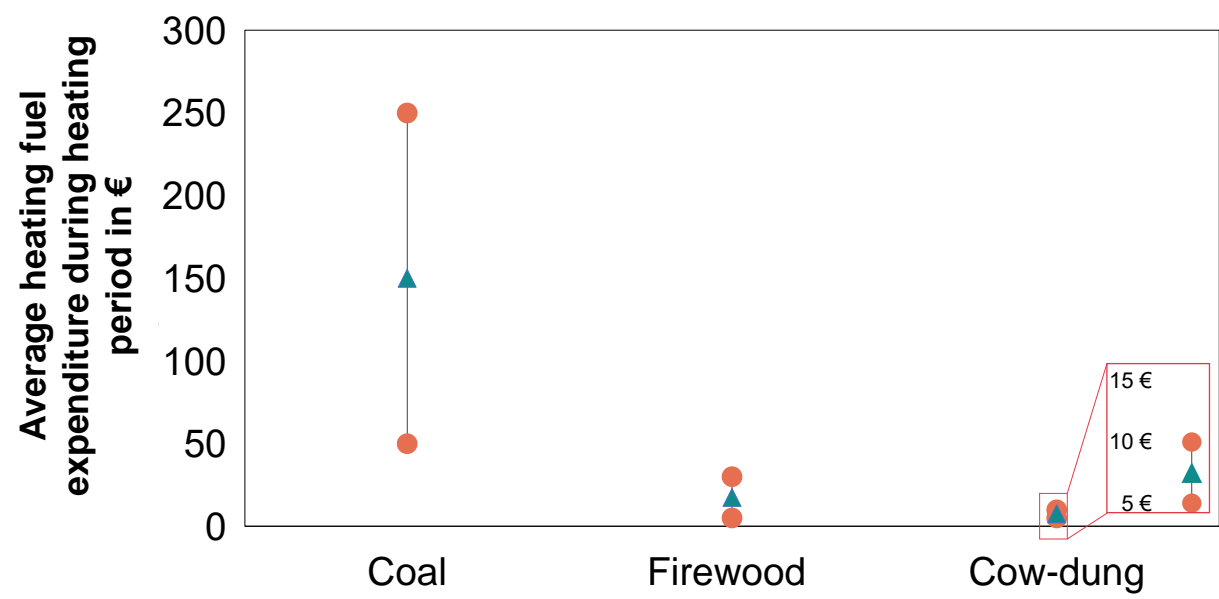

Figure 13. Heating fuel expenditure during the heating period (the costs are calculated based on the currency conversation rate in February 2020).

\subsubsection{Cooking and Cooking Pattern}

Respondents were asked about the cooking fuel type they use most frequently for cooking. The results indicate that cooking pattern varies according to the season. As mentioned in the previous section, a traditional heating stove can serve as a cooking stove. Hence, more than $80 \%$ of households practice cooking on a traditional heating stove during winter. In the other seasons, people like to switch to electric cooking. Apart from an electric stove, Ochok is a homemade outdoor cooking stove operated by solid fuels, mostly with coal and firewood. Figure 14 gives an impression of cooking patterns through various seasons.

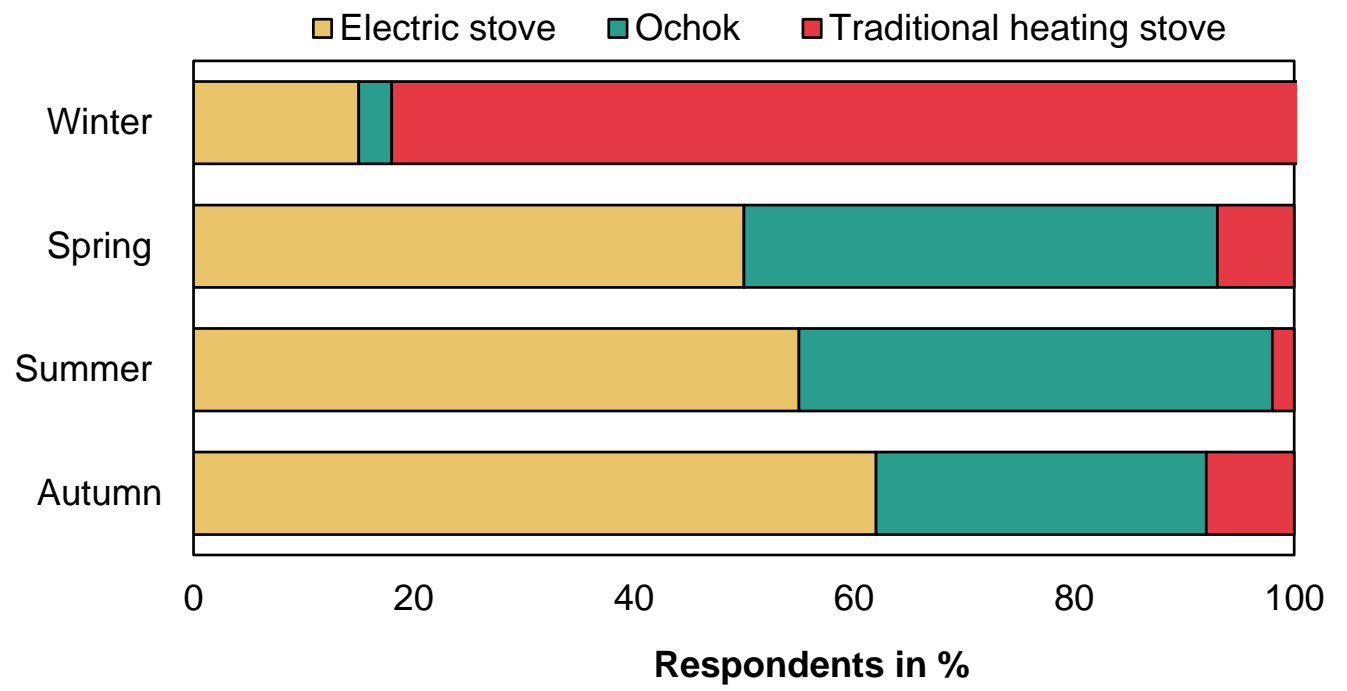

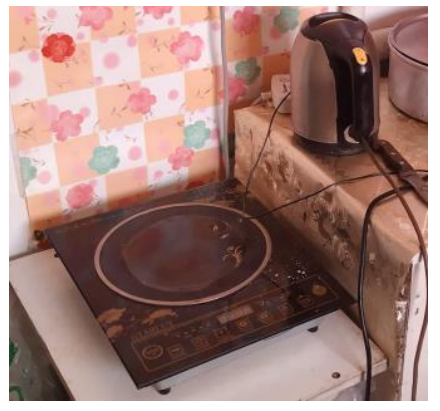

(a)

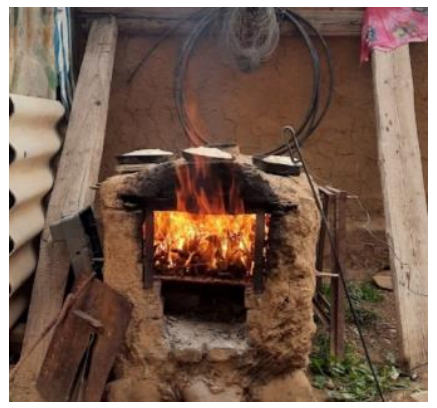

(b)

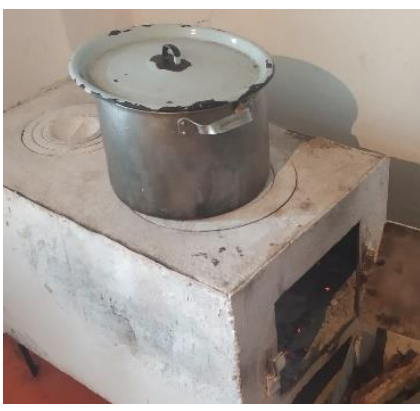

(c)

Figure 14. The identified cooking pattern according to season and cooking equipment (a) electric stove, (b) Ochok, and (c) cooking with a traditional heating stove $(N=40)$. 


\subsubsection{Hot Water Preparation}

Most of the houses are not equipped with the domestic hydraulic setup as well as not having an inbuilt shower room to use the hot water. However, they use hot water for cooking, washing clothes, dishes, etc. The precise data on the consumption of hot water is not known by the household as they fetch the water from the outside (i.e., well and river). Therefore, no water meter is available to measure hot water usage. The way of heating water varies from household to household according to their preference. Most households use the combination of an electric kettle and a traditional heating stove to prepare the hot water.

\section{Capturing Energy Profile and Trajectory for a Sustainable Energy Transition}

The previous chapter of the research article has provided a detailed overview of the complex energy situation to meet the primary energy needs of high-altitude rural Kyrgyz people. The rural population generally benefits less from economic and infrastructural development than the substantial population cluster in urban areas. Because of that, the rural population highly rely on the surrounding. Based on the above discussion, the energy pattern was derived by summarizing the three pillars plotted in Figure 15.

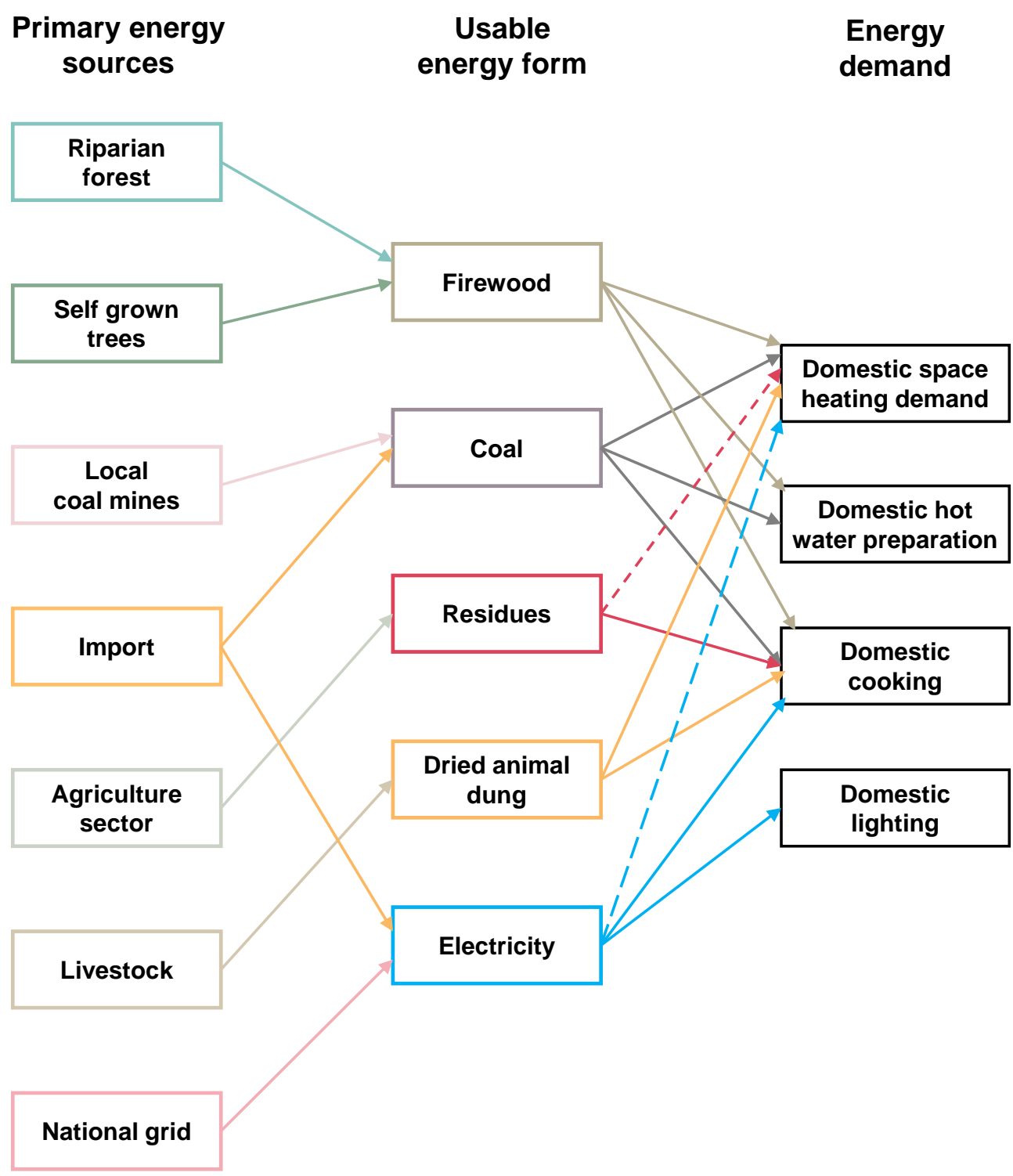

Figure 15. Energy supply and consumption pattern of high-altitude rural Kyrgyz settlement: Solid line represents the direct use, and dashed line represented the partial use (own illustration based on the on-site visit). 
The energy supply and consumption pattern clarify the catalogue of the energy behavior of rural Kyrgyzstan. It is essential to understand the driving factors that drive the household energy consumption pattern and/or are responsible for the traditional energy approach. An inadequate energy-related analysis is a major impediment to decoding the complex energy structure. In that regard, the introduced results can be adaptable to other high-height rural communities as the energy circumstance is uniform. The derivation of such factors helps to unlock the potential solutions to preserve the local ecosystems, which are described consequently.

\subsection{Driving Factors for Traditional Energy Approach}

According to survey results, people would like to heat their homes from October to March. This means that the heating season lasts for six months in the case study area. In general, this is true for the whole of Kyrgyzstan. The household survey identified the relation between income and heating period, which is explained subsequently. Because of subzero temperature and snow-covered land, the agriculture process slows down during the wintertime. The vegetation period is short, and the cultivation of the crops is always challenging/difficult. As cold weather frequently hampers agricultural production, the local farmers create less revenue, limiting their ability to afford the energy expenses.

During the winter period, the country cannot produce enough raw foods (i.e., vegetables, fruits, and grains) in cooperation with demand. In that case, Kyrgyzstan relies on the neighboring countries to import food. Naturally, the imported items are costlier than the ones own-produced; therefore, the winter is more expensive for Kyrgyz citizens than the summertime. In addition to that, the coal demand is hiked because urban households who are not connected with the district heating start using coal-operated low-pressure boilers as well as electricity-based heating radiators. This situation is solely responsible for the raising of the price of coal.

In addition, during the winter, the electricity supply is inconsistent and yields frequent power shortages and/or voltage fluctuation. These circumstances lead rural people to use the traditional approach to meet the primary energy needs. Energy price is an essential factor that impacts the selection of energy sources to meet household energy. For example, local biomass resources are readily available, while commercial energies are costlier for rural households due to their low income. Hence, the energy cost plays a crucial role in the selection of energy services. Naturally, the development of the legislative framework about energy costs easily inspires the household energy consumption pattern. The previous literature identified that the higher the energy price, the lower the acceptance among the rural people $[19,20]$.

To reduce the economic burden, villagers collect heating fuel or purchase and store it whenever they have the financial capacity. The financial situation is more robust during the summertime as the agriculture fields are in action as well as because of the active pasture lands and livestock. Hence, $98 \%$ of households reported that they are trying to purchase solid fuels in advance of the heating period. Figure 16 represents the interconnection between monthly average temperature, heating degree days (HDD), and income status. The income categories were developed based on the survey results. 


\begin{tabular}{|c|c|c|c|c|c|c|c|c|c|c|c|c|}
\hline \multirow{2}{*}{$\begin{array}{l}\text { Season } \\
\text { Month }\end{array}$} & \multicolumn{3}{|c|}{ Winter } & \multicolumn{3}{|c|}{ Spring } & \multicolumn{3}{|c|}{ Summer } & \multicolumn{3}{|c|}{ Autumn } \\
\hline & Dec & Jan & Feb & Mar & Apr & May & Jun & Jul & Aug & Sept & Oct & Nov \\
\hline Avg. temp $\left({ }^{\circ} \mathrm{C}\right)$ & 10.29 & -13.9 & -10.18 & -0.26 & 8.5 & 12.51 & 15.63 & 17.18 & 17.69 & 13.83 & 7.08 & 0.05 \\
\hline HDD & 913 & 1015 & 833 & 627 & 328 & 212 & 109 & 52 & 50 & 139 & 359 & 606 \\
\hline Income status & \multicolumn{3}{|c|}{ Lowest / No income } & \multicolumn{3}{|c|}{ Low income } & \multicolumn{3}{|c|}{ Highest income } & \multicolumn{3}{|c|}{ Medium / High income } \\
\hline
\end{tabular}

Figure 16. A generalized interconnection of income and heating period (for temperature and heating degree days, weather data from Naryn city were utilized) (higher values are shown in red, and lower values are presented in green).

Apart from financial and climatic circumstances, the current building situation and inappropriate construction techniques are key factors that lead to more solid fuel consumption inside the houses. Since the independence of Kyrgyzstan in 1991, residential construction has continued to follow the old approach from the Soviet era, with most rural homes continuing to be built with earthen materials. Between 1950 and 1960, energy costs were low, and residential buildings were constructed with very little consideration of energy efficiency. This can be considered as a historical imprint. In addition, the limited transportation network to the remote settlements, the building material supply chain of modern construction materials (such as perforated bricks, industry processed insulation materials, etc.) has not yet reached the high-altitude rural settlements.

The majority of the building materials in Kyrgyzstan are imported from neighboring countries (especially from Turkey, China, Kazakhstan, and Russia) to Bishkek. The building material supply chain does exist in capital and urban areas. However, rural areas are not profited because of their interior positions. Most of the houses are without any regard of energy efficiency in the combination of cold climatic characteristics exposed least thermal comfort inside the rural houses.

To maintain thermal comfort inside their houses, rural people mostly use coal in the combination of firewood and cow dung. However, the high-altitude locations of such communities make the coal supply/delivery difficult and costly. Irregular and costly coal supply forces rural families (predominantly low-income households) to extract firewood from the nearby riparian forests. Previous researchers have identified that overdependency on the riparian forests leads to deforestation and mutilation of local ecosystems [2]. Family energy behavior (decision making about selecting the energy sources), livelihood strategy, and knowledge are also vital factors affecting household energy consumption. For instance, low-income rural families tend to use noncommercial energy sources (low cost) because of their local circumstances as well as limit their fuel expenditures to save money.

As a corollary of high-altitude and remote locations, rural communities are not coupled with the modern energy services which generally exist in capital and nearby areas. After the economic collapse due to the dissolution of the Soviet Union, the major economic activities were reestablished in the urban sites. However, the rural settlements were left behind. This situation is responsible for less population density in high-altitude settlements.

The aforementioned factors have a high impact on energy demand, energy consumption, and energy supply directly or indirectly. It is difficult to rank the factors for traditional energy use/high dependency on the environment as they all are interlinked with each other. To present the interconnection between factors, Figure 17 portrays the interrelation of various factors. The listed factors and interrelation were plotted based on the opinion of local people and experts (from energy, social, agricultural, and building fields) working in Kyrgyzstan. It can be outlined from the expert opinion that geographical situation (high altitude, remote location, and cold climate), seasonal income, limited money to spend on electricity, absence of modern energy services, and current building stocks are substantially accountable for the traditional energy approach. 


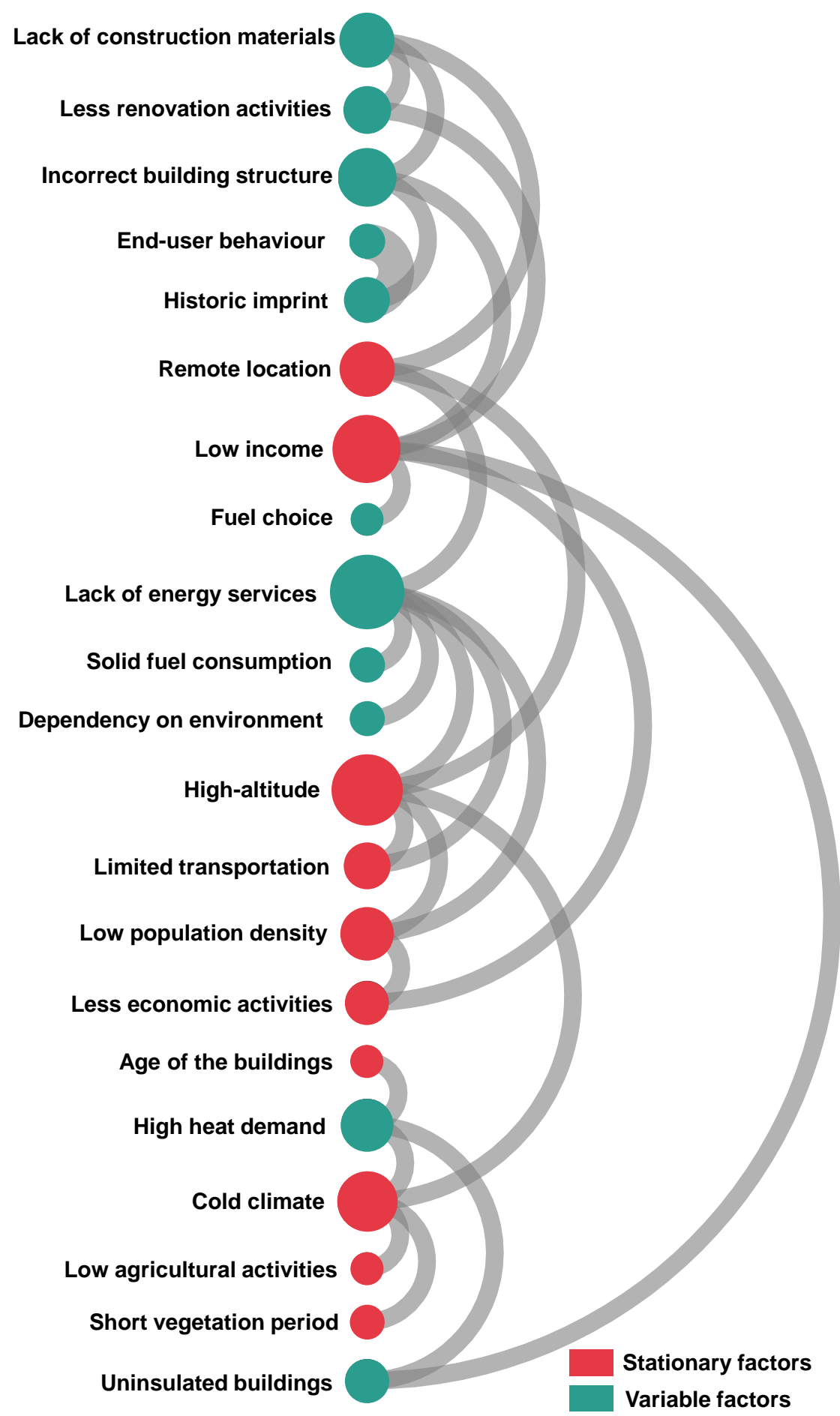

Figure 17. Factors influencing the traditional energy approach and the interrelationship (the greater bubble size represents more connections).

The presented research further differentiated the derived factors into the stationary and variable categories. The stationary (fix) variables are the ones that cannot be changed. For example, the geographical characteristics, climatic profile, and demographics are not changeable. Such factors have the same impact on the energy usage pattern. However, at the same time, the variable factors such as building energy efficiency, solid fuel consumption, energy services, etc., can be changed. For example, space heating demand in rural areas is aggravated due to the absence of insulation parameters and inappropriate building structures. This can be immediately reduced by implementing the insulation/energy effi- 
ciency parameters, which significantly affect energy supply. The derived variable factors can be focused to develop a future strategy to improve rural livelihoods. The special focus on the variable factors would help to substantially solve the classic energy issues of high-altitude rural Kyrgyz communities. The derivation of the driving factors is critically significant to outline and project the energy transition process, especially when it concerned the rural settlements in Kyrgyzstan.

The scope of the energy transition is directly or indirectly connected to preserving the ecosystems. Thus, a methodical explanation of the driving factors would be valuable outcomes that offer the fundamental linkage between rural livelihoods and the provision of modern energy services.

\subsection{A Way to Environmental Sustainability: A Brief Overview}

Access to modern and sufficient energy services is a critical component of achieving the Sustainable Development Goals (Goal 7: Affordable and clean energy). A substantial amount of conventional resources are abstracted at the country's disposal. Besides the conventional energy resources, Kyrgyzstan has great potential for variable renewable energy sources such as solar, wind, and biomass energy. It was reported in the literature that the employment of renewable energy to provide energy services could ensure sustainability in Kyrgyzstan. However, there has been a significant shortage of renewable energy-based energy generation and supply systems in Kyrgyzstan. Out of the other available untapped renewable energy resources, solar energy is considered one of the pioneer sources. The solar potential of Kyrgyzstan is almost $60 \%$ higher than in European countries [1,5,13,21,22]. However, the available vast energy resources are not exploited in favor of local rural communities because of the limited infrastructure. It was also recognized that the current energy policy with a low feed-in tariff is considered as one of the key barriers to developing the renewable energy sector in Kyrgyzstan [5,13]. The sustainable pathway and energy solution depend on various factors described earlier in this article.

In rural Kyrgyzstan, it is critical to assess whether a sustainable energy supply model is both low cost and viable. Individual improvements (i.e., insulating the dwellings, installing high-efficiency traditional heating stoves, and plantation of fast-growing trees for energy supply) are likely to be less expensive than a classic community energy solution (i.e., $\mathrm{DH}$ network). Naturally, any technical solution (such as incorporating a large share of solar thermal into a community-owned heating plant, thermo-siphon systems, microdigesters for biogas production, and so on) would always be costly (capital cost). Nonetheless, the local circumstances particularly the low-income and restricted information can be a deterrent to the sustainable energy adaption in Kyrgyzstan.

Thus, to leverage the sustainable energy transition, there is a requirement for a comprehensive arrangement that can address the social, economic, and technical issues by considering the different factors introduced in the present article. Furthermore, the local government needs to foster the fundamental components for the operation and conduction of sustainable sources in terms of legal and economic aspects.

\subsection{Potential Recommendations}

Although a lot of research remains to be conducted, the present work generated important findings in the field of energy-related information of the floodplain community. The presented findings were derived from the on-site household survey, which provided a complete picture of energy usage behavior from rural Kyrgyzstan. To integrate renewable energies, it is essential to consider the following suggestions and recommendations which are articulated as a key outcome of the household survey assessment.

Buildings are the highest energy consumers as they are built without any insulation and proper construction techniques. Vernacular architectures yield to the high heat demand of rural buildings. In that regard, introducing the energy efficiency measures (i.e., building insulation and renovation based on thermal improvement) seems the promising solution to reduce the heat demand of the houses. However, it is challenging to install more energy- 
efficient building features (such as draught-proof windows, insulation, reduced thermal bridges, etc.) all at once for rural people due to their low income, limited and concentrated supply chain of building materials, price of the building materials, and lack of knowledge and expertise. The reduced heat demand opens the door for integrating renewable energies in rural Kyrgyzstan.

As stated earlier, modern building materials are costly and rarely available for the rural population. In that case, there is a need to identify the materials that are locally obtainable and useful for improving the thermal energy efficiency of rural buildings. For example, Mehta et al. [8] identified the effectiveness of various thermal insulation materials that are available locally (i.e., sheep wool, reed panel, and straw bale) on the annual space heating demand of a high-altitude single-family rural Kyrgyz house. The results demonstrated that such materials have a substantial potential to reduce the heat demand drastically and can be economically feasible as well. The introduction of sustainable materials helps to save a considerable amount of space heating demand by up to 30\% in the case of existing houses and up to $70 \%$ for new houses in rural Kyrgyzstan. Such a selection of locally available materials can make the communities independent in terms of improving the thermal efficiency of the houses as it does not require one to depend on modern materials. The thermal efficiency measure can solve the energy-related issues simultaneously. This can be confirmed with the variable factors mentioned in Figure 17. Hence, one should focus on the building energy efficiency topic to initiate the sustainable energy transition.

\subsection{Limitations of the Study}

The small sample size can be considered as the limitation of the presented study. In addition, the prices for solid fuels frequently change in rural Kyrgyzstan. Additionally, there were no exact measures available to identify the accurate solid fuel consumption of households. Furthermore, the fuel consumption can be varied per heating season according to the financial capacity of individual households. Despite those factors, the presented work demonstrated the catalog of the energy profile of high-altitude floodplain communities, which can be served as the solid base for designing any kind of energy supply system. The multifaced energy-based household survey revealed the ground reality about the building energy situations in the rural communities of Kyrgyzstan.

\section{Conclusions}

The floodplains ecosystems along the Naryn River are in the natural state, and their ecosystems provide essential services to the local population. However, because of the absence of modern energy services in the rural/interior areas of Kyrgyzstan, local people are overexploiting the local ecosystems to extract their primary energy needs. In addition, the overuse of solid fuels for house heating considerably contributes to indoor and outdoor air pollution. To resolve the issue, the integration of renewable energy can provide a multifaced solution as it can supply sustainable energy to local people and at the same time help to reduce the progressive destruction from the regional ecosystems. This is one of the key pathways to preserve the local ecosystems in Kyrgyzstan.

To incorporate renewable energies in any region, it is essential to understand the energy usage behavior of the local people first. However, so far, there has been a research gap about the energy identity of a typical floodplain community. To bridge the gap, the presented research article illustrated the energy supply and consumption pattern of Ak-Tal (a floodplain community) by performing the household survey. The article demonstrated the in-depth assessment of the energy situation of the floodplain community by providing comprehensive information about the building structure, occupant behavior, energy use, energy supply, energy consumption, energy expenditure, thermal comfort, and potential of energy efficiency.

The detailed overview helped to illustrate the energy identity of the floodplain community. It can serve as the solid base for designing the renewable energy-assisted supply system to preserve the local ecosystems. In summary, the article recapitulates the important 
factors responsible for the traditional energy approach, which are immediately linked with the use of resources from local ecosystems. The derived interrelationship of the various drivers is the research significance of the presented study. The article concluded the meaningful recommendations for the sustainable energy transition in rural Kyrgyzstan. Based on their location and characteristics, the presented results can be partially transferable to the other rural Kyrgyz communities.

Author Contributions: Conceptualization, K.M.; investigation, K.M., S.M., N.D. and K.A.; methodology, K.M., M.E., S.M. and W.Z.; resources, N.D. and K.A.; supervision, W.Z.; visualization, K.M.; writing-original draft, K.M.; writing—review and editing, M.E. All authors have read and agreed to the published version of the manuscript.

Funding: The research work was funded by the Federal Ministry of Education and Research (BMBF) of the Federal Republic of Germany within the CLIENT II funding programme International Partnerships for Sustainable Innovations under the project "ÖkoFlussPlan" (Project ID 01LZ1802A-F).

Data Availability Statement: Not applicable.

Acknowledgments: The author would like to acknowledge the support and contribution of the students and staff from Naryn State University to perform the housed survey in the local language. In addition, the authors like to acknowledge the local self-governance of Ak-Tal and local people of the Ak-Tal community to cooperate during the household survey. We extend our gratitude to the participants for providing the necessary information.

Conflicts of Interest: The authors declare no conflict of interest.

\section{References}

1. Degembaeva, N.; Baibagyshov, E.; Betz, F.; Cyffka, B.; Lauermann, M.; Ayipov, B. Floodplain Areas along the Naryn River in Kyrgyzstan: Assessment of Hydrological and Climate Changes, and Its Dynamics. Available online: https://edoc.ku.de/id/ eprint/25576/1/Degembaeva_Naryn_River_2020.pdf (accessed on 15 November 2021).

2. Lauermann, M.; Betz, F.; Mehta, K.; Thevs, N.; Ehrenwirth, M.; Zörner, W.; Cyffka, B. Preservation of Selected Ecosystem Services in the Floodplains of the Naryn River (Kyrgyzstan): Introducing the ÖkoFlussPlan Project. In Geographica Augustana; Institut für Geographie, Universität Augsburg: Heidelberg, Germany, 2020; pp. 47-53; ISBN 1862-8680.

3. Karthe, D.; Chalov, S.; Borchardt, D. Water resources and their management in central Asia in the early twenty first century: Status, challenges and future prospects. Environ. Earth Sci. 2015, 73, 487-499. [CrossRef]

4. Betz, F.; Rauschenberger, J.; Lauermann, M.; Cyffka, B. Using GIS and Remote Sensing for Assessing Riparian Ecosystems along the Naryn River, Kyrgyzstan. Int. J. Geoinformatics 2016, 12, 25-30.

5. Mehta, K.; Ehrenwirth, M.; Trinkl, C.; Zörner, W.; Greenough, R. The Energy Situation in Central Asia: A Comprehensive Energy Review Focusing on Rural Areas. Energies 2021, 14, 2805. [CrossRef]

6. UNICEF. Climate Analysis for Children in Kyrgyzstan: Working Paper, 2017. Available online: https://www.unicef.org/ kyrgyzstan/media/1526/file/Kyrgyzstan\%20Climate\%20Landscape\%20Analysis\%20for\%20Children.pdf\%20.pdf (accessed on 1 November 2021).

7. Khan, F.; Sohail, Z.; Khan, T.; Fatima, B.; Malik, F.; Bukhari, S.F.H.; Imadi, S.R.; Gul, A. Deforestation: A Continuous Battle-A Case Study from Central Asia and Other Countries. In Vegetation of Central Asia and Environs; Egamberdieva, D., Öztürk, M., Eds.; Springer International Publishing: Cham, Switzerland, 2018; pp. 73-117; ISBN 978-3-319-99727-8.

8. Mehta, K.; Ehrenwirth, M.; Trinkl, C.; Zörner, W.; Greenough, R. Impact of Locally Available Thermal Insulation Structures on Space Heating Demand of High-altitude Rural Buildings: A Case Study of Kyrgyzstan. In Proceedings of the EuroSun 2020, Virtual Conference, 1-3 September 2020.

9. Brakema, E.A.; Tabyshova, A.; Kasteleyn, M.J.; Molendijk, E.; van der Kleij, R.M.J.J.; van Boven, J.F.M.; Emilov, B.; Akmatalieva, M.; Mademilov, M.; Numans, M.E.; et al. High COPD prevalence at high altitude: Does household air pollution play a role? Eur. Respir. J. 2019, 53, 1801193. [CrossRef] [PubMed]

10. Grimm, N.B.; Chapin, F.S.; Bierwagen, B.; Gonzalez, P.; Groffman, P.M.; Luo, Y.; Melton, F.; Nadelhoffer, K.; Pairis, A.; Raymond, P.A.; et al. The impacts of climate change on ecosystem structure and function. Front. Ecol. Environ. 2013, 11, 474-482. [CrossRef]

11. Malhi, Y.; Franklin, J.; Seddon, N.; Solan, M.; Turner, M.G.; Field, C.B.; Knowlton, N. Climate change and ecosystems: Threats, opportunities and solutions. Philos. Trans. R. Soc. Lond. B Biol. Sci. 2020, 375, 20190104. [CrossRef] [PubMed]

12. Li, G.; Sun, J.; Dai, A. Village differences in rural household energy consumption within the Loess hilly region of China. Energy Sustain. Soc. 2016, 6, 6. [CrossRef]

13. Laldjebaev, M.; Isaev, R.; Saukhimov, A. Renewable energy in Central Asia: An overview of potentials, deployment, outlook, and barriers. Energy Rep. 2021, 7, 3125-3136. [CrossRef] 
14. Baybagyshov, E.; Degembaeva, N. Analysis of usage of the renewable energy in Kyrgyzstan. IOP Conf. Ser.: Earth Environ. Sci. 2019, 249, 12021. [CrossRef]

15. Singh, A.S.; Masuku, M.B. Sampling Techniques and Determination of Sample Size in Applied Statistics Research: An Overview. Int. J. Econ. Commer. Manag. 2014, 2, 1-22.

16. UNDP. Improving Energy Efficiency in Buildings. Available online: https://www.kg.undp.org/content/kyrgyzstan/en/home/ operations/projects/sustainable_development/energy-efficiency-buildings.html (accessed on 12 October 2021).

17. Hall, K. Supporting Energy Efficiency and Renewables Uptake in Rural Communities in Mountainous Kyrgyzstan; Mountain Societies Research Institute: Bishkek, Kyrgyzstan, 2018.

18. Boronbaev, E. Energy saving Architecture: Background, Theory and Practice in Kyrgyzstan. E3S Web Conf. 2020, 172, 19010. [CrossRef]

19. Gassner, K.B.; Rosenthal, N.; Hankinson, D.J. Analysis of the Kyrgyz Republic's Energy Sector: Final Report; World Bank Energy and Extractives Global Practice ECA Region: Washington, DC, USA, 2017. Available online: https:/ / openknowledge.worldbank.org/ handle/10986/29045 (accessed on 20 September 2018).

20. Laldjebaev, M. Energy Security, Poverty and Sovereignty in Mountain Communities of Tajikistan. Ph.D. Thesis, Cornell University, New York, NY, USA, 2017.

21. Liu, M.F.; Pistorius, T. Coping with the energy crisis: Impact assessment and potentials of non-traditional renewable energy in rural Kyrgyzstan. Energy Policy 2012, 44, 130-139. [CrossRef]

22. Mehta, K.; Ehrenwirth, M.; Trinkl, C.; Zörner, W.; Greenough, R. A Parametric Study on the Feasibility of Solar-thermal Space Heating and Hot Water Preparation under Cold Climates in Central Asian Rural Areas. In Proceedings of the EuroSun 2020, Virtual Conference, 1-3 September 2020. 